\title{
The Critical Role of Phosphate in Vanadium Phosphate Oxide for the Catalytic Activation and Functionalization of $n$-Butane to Maleic Anhydride
}

\author{
Mu-Jeng Cheng and William A. Goddard, III* \\ Materials and Process Simulation Center, California Institute of Technology, Pasadena, California 91125, United States
}

Supporting Information

ABSTRACT: We used density functional theory to study the mechanism of $n$-butane oxidation to maleic anhydride on the vanadium phosphorus oxide (VPO) surface. We found that $\mathrm{O}(1)=\mathrm{P}$ on the $\mathrm{V}^{\mathrm{V}} \mathrm{OPO}_{4}$ surface is the active center for initiating the VPO chemistry through extraction of $\mathrm{H}$ from alkane $\mathrm{C}-\mathrm{H}$ bonds. This contrasts sharply with previous suggestions that the active center is either the $\mathrm{V}-$ $\mathrm{O}$ bonds or else a chemisorbed $\mathrm{O}_{2}$ on the $\left(\mathrm{V}^{\mathrm{IV}} \mathrm{O}\right)_{2} \mathrm{P}_{2} \mathrm{O}_{7}$ surface. The ability of $\mathrm{O}(1)=\mathrm{P}$ to cleave alkane $\mathrm{C}-\mathrm{H}$ bonds is due to its strong basicity coupled with large reduction potentials of nearby $\mathrm{V}^{\mathrm{V}}$ ions. We examined several pathways for the subsequent functionalization of $n$ butane to maleic anhydride and found that the overall barrier does not exceed $21.7 \mathrm{kcal} / \mathrm{mol}$.

$\mathrm{V}$ anadium phosphorus oxide (VPO) is a unique catalyst that converts $n$-butane to maleic anhydride (MA) with high selectivity $(60-70 \%) .^{1}$ Because of the industrial importance of this catalyst (used to produce $500 \mathrm{kton}$ of MA annually), ${ }^{1 a}$ numerous efforts have been devoted to understanding this unique catalytic reaction in order to improve the yield of MA from the current value of 50\%. ${ }^{1 \text { a }}$ Such improvements in yield would bring enormous economic and environmental benefits. We believe that a major impediment here is the lack of atomistic-level reaction mechanisms to focus attention on the atomistic origins of the critical barriers for the selective and unselective processes. Here we report progress toward this goal.

Despite numerous experimental ${ }^{1}$ and a few theoretical ${ }^{2}$ studies, the mechanism of the catalytic oxidation reaction remains under debate. Some suggest that the oxidation follows an olefinic route, ${ }^{3}$ during which reaction intermediates desorb, whereas others suggest that the reaction follows an alkoxide route, ${ }^{4}$ in which $n$-butane is anchored on the surface after the initial $\mathrm{C}-\mathrm{H}$ activation and desorbs only when MA has been formed. Besides the uncertainty in the mechanism, such basic questions as which sites on the surface are active centers for the initial $n$-butane $\mathrm{C}-\mathrm{H}$ bond cleavage remain unanswered. ${ }^{1 \mathrm{~b}, 5}$

Here we report density functional theory (DFT) calculations aimed at elucidating the critical steps for this catalytic system. We propose that the first step of the reaction is the oxidation of $(\mathrm{VO})_{2} \mathrm{P}_{2} \mathrm{O}_{7}$ (denoted as VOPO, the major component of VPO) by gaseous $\mathrm{O}_{2}$ to form a metastable phase of $\mathrm{VOPO}_{4}$. The surface of $\mathrm{VOPO}_{4}$ contains highly reactive phosphine-oxo bonds $[\mathrm{P}=\mathrm{O}(1)]$ that extract $\mathrm{H}$ from the methylene groups of $n$-butane with a barrier of only $13.5 \mathrm{kcal} / \mathrm{mol}$, consistent with the experimental data. ${ }^{6}$ Our findings contrast with previous studies suggesting that the active centers are either surface $\mathrm{V}-$ $\mathrm{O}$ bonds ${ }^{16}$ or adsorbed $\mathrm{O}_{2},{ }^{5}$ with the assumption that pyrophosphate or phosphate is an innocent linked ligand. Moreover, we propose a full sequence of reactions for the conversion of $n$-butane to MA involving the consecutive oxidation of $n$-butane to 2-butene, butadiene, 2,5-dihydrofuran, crotonlactone, and MA with an overall barrier of only 21.7 $\mathrm{kcal} / \mathrm{mol}$. This constitutes the first computational investigation to identify the active sites as the $\mathrm{O}(1)=\mathrm{P}$ bonds of $\mathrm{VOPO}_{4}$ and to propose a full reaction mechanism for the VPOcatalyzed oxidation of $n$-butane all the way to MA. This mechanism should provide valuable hints for optimization of these catalysts.

We first carried out a full optimization of the VOPO bulk structure (Figure 1), including atomic positions and cell

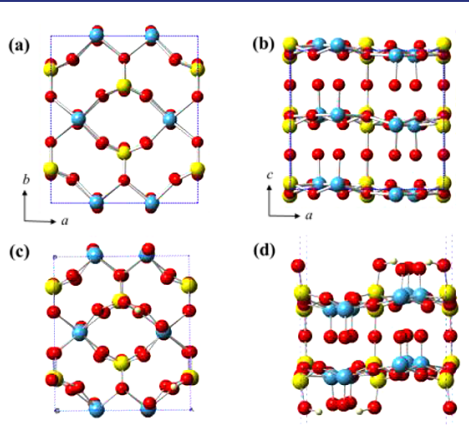

Figure 1. (a, c) Top and (b, d) side views of (a, b) bulk and (c, d) surface VOPO. Blue, yellow, red, and white balls represent V, P, O, and $\mathrm{H}$, respectively.

parameters under orthorhombic symmetry [see the Supporting Information (SI)]. The VOPO surface model used in this work was prepared by cutting the DFT-optimized bulk structure parallel to the $a b$ plane, cleaving the $\mathrm{P}-\mathrm{O}-\mathrm{P}$ interlayer bonds. It is generally agreed that the active sites involved in $n$-butane oxidation to MA are located on this surface. ${ }^{1,7}$ We capped the cleaved sites with either $\mathrm{H}$ atoms or $\mathrm{OH}$ groups to maintain $\mathrm{V}$ and $\mathrm{P}$ in the +4 and +5 oxidation states, respectively, while keeping the surface unit cell neutral. The total number of atoms in the unit cell is 58, which includes eight $\mathrm{V}$, eight $\mathrm{P}$, four $\mathrm{OH}$,

Received: November 26, 2012

Published: February 24, 2013 
and $34 \mathrm{O}$ atoms. Saturating the cleaved $\mathrm{P}-\mathrm{O}$ bonds in this way is reasonable since Busca et al. ${ }^{7}$ observed that such $\mathrm{P}-\mathrm{OH}$ motifs exist on the VOPO surface with vibrational frequencies of $2600-3600 \mathrm{~cm}^{-1}$.

We evaluated the $\mathrm{C}-\mathrm{H}$ activation power of various $\mathrm{O}$ and $\mathrm{V}$ atoms on the VOPO surface by calculating the binding energies of these atoms to a free $\mathrm{H}$ atom $\left(D_{\mathrm{H}}\right)$ (see the SI for details). ${ }^{8}$ Surprisingly, we found that none of the surface $\mathrm{O}$ or $\mathrm{V}$ atoms can carry out facile $n$-butane $\mathrm{C}-\mathrm{H}$ activation. The largest $D_{\mathrm{H}}$ value, from the $\mathrm{O}(1)=\mathrm{V}$ (vanadyl) group, was only $58.2 \mathrm{kcal} /$ mol, compared with a bond dissociation energy of $98.3 \mathrm{kcal} /$ $\mathrm{mol}^{9}$ for the weakest $\mathrm{C}-\mathrm{H}$ bond in $n$-butane. Therefore $\mathrm{C}-\mathrm{H}$ cleavage by $\mathrm{O}(1)=\mathrm{V}$ would pose a barrier of $>40.0 \mathrm{kcal} / \mathrm{mol}$, which is far larger than the experimental value $\left(E_{\mathrm{a}}=12.9-23.6\right.$ $\mathrm{kcal} / \mathrm{mol}$, depending on the degree of oxidation of VPO). ${ }^{6}$

It has been proposed that gaseous $\mathrm{O}_{2}$ may adsorb on the VOPO surface in a molecular or dissociative fashion, oxidizing $\mathrm{V}^{\mathrm{IV}}$ to $\mathrm{V}^{\mathrm{V}}$ and forming very reactive oxygen species in the form of $\mathrm{O}^{-}, \mathrm{O}_{2}{ }^{-}$, or $\mathrm{O}_{2}{ }^{2-}{ }^{-5,10}$ We investigated this possibility and found it to be unlikely. Binding of $\mathrm{O}_{2}(\mathrm{~g})$ to the VOPO surface is uphill by $2.8 \mathrm{kcal} / \mathrm{mol}$ (electronic energy) rather than downhill (Figure 2a), even though two $\mathrm{V}^{\mathrm{IV}}$ do oxidize to $\mathrm{V}^{\mathrm{V}}$.

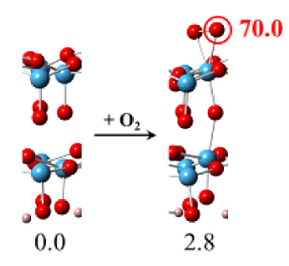

(a)

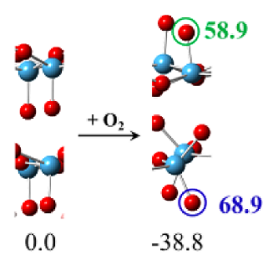

(b)
Figure 2. Energies (in $\mathrm{kcal} / \mathrm{mol}$ ) of oxygen adsorption on the $(\mathrm{VO})_{2} \mathrm{P}_{2} \mathrm{O}_{7}$ surface (black numbers) and the corresponding $D_{\mathrm{H}}$ values (colored numbers).

Moreover, chemisorption of $\mathrm{O}_{2}(\mathrm{~g})$ to $\mathrm{V}$ leads to $D_{\mathrm{H}}=70.0$ $\mathrm{kcal} / \mathrm{mol}$ for peroxyl oxygen, indicating that the $\mathrm{C}-\mathrm{H}$ activation barrier would be at least $30 \mathrm{kcal} / \mathrm{mol}$.

We also considered dissociative adsorption of $\mathrm{O}_{2}(\mathrm{~g})$ onto the VOPO surface. We added two $\mathrm{O}$ atoms atop $\mathrm{V}$ [trans to $\mathrm{O}(1)]$. Geometry optimization led to the formation of two new $\mathrm{O}=\mathrm{V}$ bonds but simultaneously pushed the two original $\mathrm{O}(1)$ atoms to bind with $\mathrm{V}=\mathrm{O}(1)$ on the second layer, forming two transdioxovanadium motifs $[\mathrm{O}(1)-\mathrm{V}-\mathrm{O}(1)]$ on the other side of the surface (Figure $2 \mathrm{~b}$ ). Löwdin spin density analysis showed that the two newly added $\mathrm{O}$ atoms possessed some radical character $(0.15 \mathrm{e})$ but had $D_{\mathrm{H}}$ values of only $58.9 \mathrm{kcal} / \mathrm{mol}$. trans-Dioxo species are rare for first-row transition metals, ${ }^{11}$ but one has recently been reported for the Mn porphyrin system ${ }^{12}$ and is known to activate weak alkane $\mathrm{C}-\mathrm{H}$ bonds. For the current VOPO system, the $D_{\mathrm{H}}$ of the trans-dioxovanadium motif is only $68.9 \mathrm{kcal} / \mathrm{mol}$, indicating a minimum barrier of $>$ $30 \mathrm{kcal} / \mathrm{mol}$ for $n$-butane $\mathrm{C}-\mathrm{H}$ activation. These results clearly indicate that neither $\mathrm{O}$ on the VOPO surface nor molecularly or dissociatively adsorbed $\mathrm{O}_{2}$ is the active site for initial n-butane C$H$ activation. From experimental studies of the same oxidation reaction catalyzed on supported vanadia, Wachs and co-workers reached the same conclusion. ${ }^{13}$

Experiments have shown that the surface of the working catalyst contains small amounts of various phases of $\mathrm{VOPO}_{4}{ }^{14}$ suggesting the possibility that $\mathrm{V}^{\mathrm{V}}$, which is known to activate alkanes and furan, ${ }^{15}$ may come from $\mathrm{VOPO}_{4}$. Interestingly, comparison of the structures of well-defined $\mathrm{VOPO}_{4}$ phases $\left(\alpha_{\mathrm{I}}, \alpha_{\mathrm{II}}\right.$ and $\left.\beta\right)$ to that of VOPO showed that no significant structural change takes place at $\mathrm{V}$ atoms. Instead the major changes are at $\mathrm{P}$ (Figures $\mathrm{S} 1$ and $\mathrm{S} 2$ in the SI). In VOPO, each $\mathrm{P}$ atom binds to one $\mathrm{O}-\mathrm{P}$ motif (forming $\mathrm{P}-\mathrm{O}-\mathrm{P}$ bonds linking two adjacent layers) and three $\mathrm{O}-\mathrm{V}$ motifs, whereas in $\mathrm{VOPO}_{4}, \mathrm{P}$ binds with four $\mathrm{O}-\mathrm{V}$ motifs. This suggests that the oxidation of VOPO to $\mathrm{VOPO}_{4}$ may occur by addition of oxygen to $\mathrm{P}$, converting one pyrophosphate into two orthophosphates (Scheme 1). In this way, two of the dative

Scheme 1. Valence-Bond Description of Pyrophosphate Oxidation $[\mathrm{O}(1)$ Atoms on $\mathrm{V}$ Have Been Omitted for Clarity]

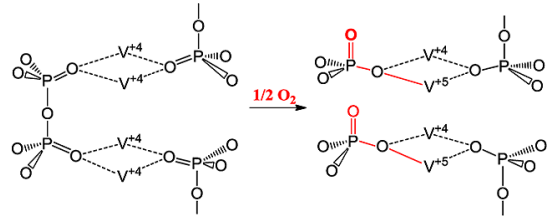

bonds in the $\mathrm{V}-(\mathrm{O})_{2}-\mathrm{V}$ motif of VOPO become covalent, and concurrently, two $\mathrm{V}^{\mathrm{IV}}$ are oxidized to $\mathrm{V}^{\mathrm{V}}$. ${ }^{2 \mathrm{a}}$ This increase in $\mathrm{V}$ oxidation state may enhance the reactivity of the surface oxygen toward $n$-butane $\mathrm{C}-\mathrm{H}$ activation.

To verify our hypothesis, we studied bulk $\mathrm{VOPO}_{4}$ and the corresponding surfaces. Besides the well-defined $\alpha_{\mathrm{I}}, \alpha_{\mathrm{I}}$, and $\beta$ phases of $\mathrm{VOPO}_{4}$ (Figure S3), we also investigated a proposed $\mathrm{X}_{1}$ phase. ${ }^{16}$ This phase is proposed to form by direct addition of an $\mathrm{O}$ atom to the $\mathrm{P}-\mathrm{O}-\mathrm{P}$ motif, after which the $\mathrm{O}(1)=$ $\mathrm{P} \cdots \mathrm{O}(1)=\mathrm{P}$ motifs are formed and $\mathrm{V}$ is oxidized to the +5 state, leading to a layered structure. We consider that this is likely to be the precursor for the formation of other phases and that the transformations involve coordination of $\mathrm{O}(1)=\mathrm{P}$ to the nearby $\mathrm{V}$ atoms.

We started by examining how surface layers of the VPO catalyst that are extensions of bulk VOPO are converted into $\mathrm{VOPO}_{4}$ via oxidation by $\mathrm{O}_{2}$. Some experimental studies suggest that the surface layers are amorphous after annealing, ${ }^{17}$ which indicates that there is no long-range order $(>25 \AA)$. For computational convenience, we assumed long-range order, but the characters of the sites that we discuss require only local order. Thus, our conclusions do not require long-range order.

We first optimized the cell parameters and atomic positions of these $\mathrm{VOPO}_{4}$ phases under orthorhombic symmetry and then evaluated the $\mathrm{C}-\mathrm{H}$ activation power of various oxygen sites on these $\mathrm{VOPO}_{4}$ surfaces, focusing on the $\alpha_{\mathrm{I}}, \alpha_{\mathrm{II}}$, and $\mathrm{X}_{1}$ surfaces because of their layered structures. All of the surfaces were prepared by cleavage parallel to the layer direction in such a way that only van der Waals interactions were broken. Surprisingly, the $D_{\mathrm{H}}$ values for the $\alpha_{\mathrm{I}}$ surface were 49.2 and 48.5 $\mathrm{kcal} / \mathrm{mol}$ for the $\mathrm{O}(1)$ and $\mathrm{O}(2)$ sites, respectively, and those for the $\alpha_{\mathrm{II}}$ surface were 52.1 and $45.2 \mathrm{kcal} / \mathrm{mol}$, respectively (Figure S4). This clearly indicates that none of the $\mathrm{O}$ sites on the $\alpha_{\mathrm{I}}$ or $\alpha_{\mathrm{II}}$ surface can be the reactive center for VPO chemistry. Although we did not evaluate the surface of the $\beta$ phase, we expect the $\beta$-phase $\mathrm{O}$ atoms to have similar $D_{\mathrm{H}}$ values, and as a result, none would be expected to present a low-barrier pathway for cleavage of alkane $\mathrm{C}-\mathrm{H}$ bonds.

Interestingly, during the course of evaluating $D_{\mathrm{H}}$ for $\mathrm{O}(1)=$ $\mathrm{V}$ on the $\mathrm{X}_{1}$ surface, we found that a hydrogen initially placed to bind with $\mathrm{O}(1)=\mathrm{V}$ was pushed by the structural 
optimization to bind with the oxygen of $\mathrm{O}(1)=\mathrm{P}$ instead. Most importantly, this led to a $D_{\mathrm{H}}$ of $84.3 \mathrm{kcal} / \mathrm{mol}$, which is 26.1 $\mathrm{kcal} / \mathrm{mol}$ larger than that for $\mathrm{O}(1)=\mathrm{V}$ on the VOPO surface and $14.3 \mathrm{kcal} / \mathrm{mol}$ larger than that of the vanadium peroxyl. Analysis of the spin density showed that although the proton was bound to $\mathrm{O}(1)=\mathrm{P}$, the electron was delocalized among two nearby $\mathrm{V}$ atoms (0.61e and $0.45 \mathrm{e}$ by Löwdin analysis). A single-point calculation using the B3LYP functional with double- $\zeta$-quality Gaussian basis sets led to a similar spin distribution. This indicates that after abstraction of $H$ by $O(1)=$ $P, V$ is reduced. A similar phenomenon was observed in the oxidative dehydrogenation of methanol to formaldehyde catalyzed by vanadia/ceria. ${ }^{18}$

We found that this highly reactive $\mathrm{O}(1)=\mathrm{P}$ site activates the $n$-butane methylene $\mathrm{C}-\mathrm{H}$ bonds with a barrier of only 13.5 $\mathrm{kcal} / \mathrm{mol}$, which is in the range of the experimentally estimated values $(12.9-23.6 \mathrm{kcal} / \mathrm{mol}){ }^{6}$ Thus, we propose that $\mathrm{O}(1)=\mathrm{P}$ on the metastable $\mathrm{X}_{1}-\mathrm{VOPO}_{4}$ surface is the active center for initiating the VPO chemistry. This conclusion is in stark contrast to the common assumption that pyrophosphate or phosphate is the linked ligand and is catalytically inactive. This is also in contrast to all previous speculations concerning the mechanism based on experimental ${ }^{1 b, 5}$ and theoretical studies, ${ }^{2}$ which suggested that the reactive center is either a $\mathrm{V}-\mathrm{O}$ bond ${ }^{1 \mathrm{~b}}$ or chemisorbed $\mathrm{O}_{2}$ on $\mathrm{V}^{5}$ Since, pyrophosphates and phosphates are common components in heterogeneous catalysts, we speculate that they may play a key role for some of these catalytic systems, as in the VPO system. ${ }^{19}$

Since V is reduced during $\mathrm{C}-\mathrm{H}$ activation, changes its reduction potential by binding it with electron-donating ligands such as water or replacing it with other metals would be expected to change the reactivity of the VPO catalyst. For example, our calculations show that for $\mathrm{V}$ bound to water, the $D_{\mathrm{H}}$ of the nearby $\mathrm{O}(1)=\mathrm{P}$ decreases from 84.3 to $78.1 \mathrm{kcal} /$ mol. This is consistent with the experiments showing that water vapor decreases the reactivity of VPO. ${ }^{20}$ The addition of other metals such as $\mathrm{Cr}, \mathrm{Fe}$, and $\mathrm{Cu}$ as promoters would be expected to change the reduction potential of the electron sink, which in turn would also be expected to change the intrinsic reactivity of VPO. Indeed, such promoters are widely used in most commercial VPO catalysts. ${ }^{21}$

Wachs and co-workers used in situ Raman spectroscopy to study the selective oxidation of $n$-butane to MA using supported vanadia catalysts. ${ }^{13}$ They found that the addition of $\mathrm{P}_{2} \mathrm{O}_{5}$ phosphate additives increased the MA selectivity from 22.8 to $56.2 \%$, on which basis they concluded that the V-O-P bond is the active site for the rate-determining step. We agree with this conclusion but find more specifically that this site is a $\mathrm{O}(1)=\mathrm{P}-\mathrm{O}-\mathrm{V}=\mathrm{O}(1)$ unit in which the phosphate is coupled through a bridging $\mathrm{O}$ to the $\mathrm{V}=\mathrm{O}(1)$ bond of $\mathrm{V}$ in the +5 oxidation state. Also, it is the $\mathrm{P}=\mathrm{O}(1)$ bond that activates the $\mathrm{C}-\mathrm{H}$ bond of $n$-butane. On the basis of the observed $n$-butane conversion rate of this model catalyst ( $12.1 \%$ vs $80 \%$ for $\mathrm{VPO}$ ), we speculate that some $\mathrm{P}-\mathrm{O}-\mathrm{P}$ bonds of the additive are retained in the model catalyst, in which case Wachs' model system may operate via the same mechanism as we discovered for VPO. The activity would be expected to be less because the model system may not have the layer-to-layer integrity of the VPO catalyst. If the model catalyst does not retain the $\mathrm{P}-\mathrm{O}-\mathrm{P}$ units, then it may operate differently. An experimental test might be to replace the $\mathrm{P}_{2} \mathrm{O}_{5}$ additive with $\mathrm{PO}_{4}$.
Utilizing a nonmetal-oxo bond (e.g., $\mathrm{P}=\mathrm{O}$ or $\mathrm{S}=\mathrm{O}$ ) to activate alkane $\mathrm{C}-\mathrm{H}$ bonds would be ideal because it would avoid the direct use of expensive metals as the active center. ${ }^{22}$ Recently, this idea was explored by Schwarz and co-workers, ${ }^{23 a}$ who used $\left[\mathrm{P}_{4} \mathrm{O}_{10}\right]^{\bullet+}$ to activate methane $\mathrm{C}-\mathrm{H}$ bonds, and by de Petris et al., ${ }^{23 \mathrm{~b}}$ who used $\left[\mathrm{SO}_{2}\right]^{\bullet+}$ to activate methane.

Our current results show that a nonmetal oxo bridged to a high-valent metal acting as an electron reservoir would be able to activate alkane $\mathrm{C}-\mathrm{H}$ bonds without being excited to the radical cation state. This idea is also valid for finite molecules. For example, $D_{\mathrm{H}}=28.2 \mathrm{kcal} / \mathrm{mol}$ for $\mathrm{P}_{4} \mathrm{O}_{10}$ (Scheme S1a in the $\mathrm{SI}$ ), but replacing one $\mathrm{O}(1)=\mathrm{P}$ motif by $\mathrm{O}(1)=\mathrm{V}$ (Scheme $\mathrm{S} 1 \mathrm{~b})$ increases $D_{\mathrm{H}}$ to $60.5 \mathrm{kcal} / \mathrm{mol}$. We expect that $D_{\mathrm{H}}$ would be larger if a more electrophilic high-valent metal ion such as $\mathrm{Fe}$ or Co were used. This concept may be utilized to design a new class of homogeneous $\mathrm{C}-\mathrm{H}$ activation catalysts.

To demonstrate that our proposed highly reactive $\mathrm{X}_{1}$ $\mathrm{VOPO}_{4}$ surface is able to convert $n$-butane all the way to MA, we studied the subsequent steps of this oxidation reaction with a one-layer model (Figure 3). In this preliminary reaction

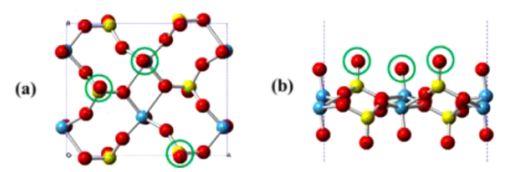

Figure 3. One-layer model of the $\mathrm{X}_{1}-\mathrm{VOPO}_{4}$ surface. Green circles mark sites involved in oxidation of $n$-butane to MA.

mechanism study, we focused on the olefinic mechanism, in which $n$-butane is converted sequentially to butene, butadiene, dihydrofuran, crotonlactone, and finally $\mathrm{MA}^{3,24}$ with the product of each conversion desorbing and then reacting with a fresh surface.

The oxidative dehydrogenations of $n$-butane to 2-butene and 2-butene to butadiene (Figure $4 a, b$ ) and the oxidations of 2,5-

(a)

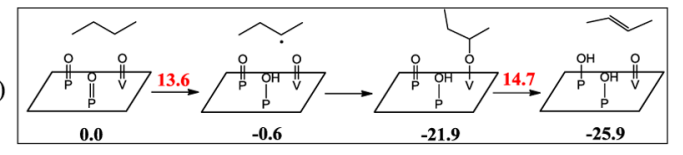

(b)

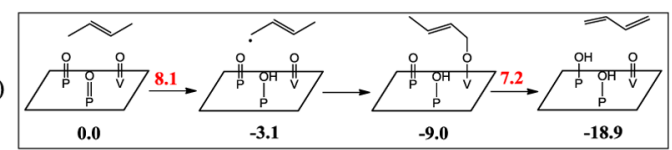

(c)

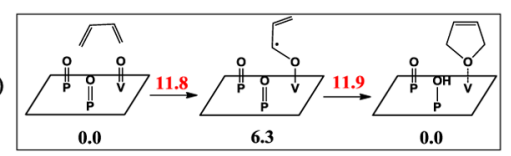

(d)

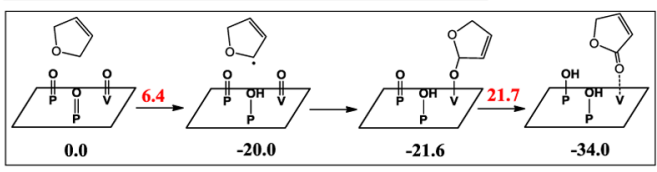

(e)

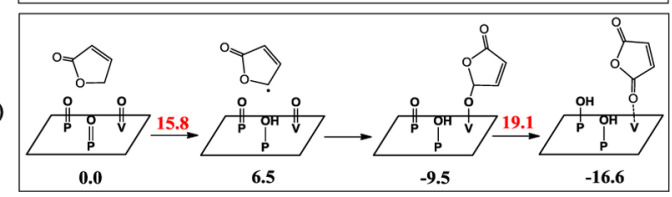

Figure 4. Schematic description of a pathway for oxidation of $n$-butane all the way to MA. Black and red numbers represent potential energies and reaction barriers, respectively, in $\mathrm{kcal} / \mathrm{mol}$. 
dihydrofuran to crotonlactone and crotonlactone to MA (Figure $4 \mathrm{~d}, \mathrm{e}$ ) proceed by similar pathways: $\mathrm{H}$ abstraction by $\mathrm{O}(1)=\mathrm{P}$, with trapping of the hydrocarbyl radical on $\mathrm{O}(1)=$ $\mathrm{V}$, and a second $\mathrm{H}$ abstraction by another $\mathrm{O}(1)=\mathrm{P}$. The highest barriers are $14.7 \mathrm{kcal} / \mathrm{mol}$ for $n$-butane $\rightarrow$ 2-butene, 8.1 $\mathrm{kcal} / \mathrm{mol}$ for 2-butene $\rightarrow$ butadiene, $21.7 \mathrm{kcal} / \mathrm{mol}$ for 2,5 dihydrofuran $\rightarrow$ crotonlactone, and $19.1 \mathrm{kcal} / \mathrm{mol}$ for crotonlactone $\rightarrow$ MA. The conversion of butadiene to 2,5dihydrofuran (Figure 4c) involves $\mathrm{C}-\mathrm{O}$ formation and a ringclosing step, with a highest barrier of $18.2 \mathrm{kcal} / \mathrm{mol}$. The overall reaction barrier for the oxidation of $n$-butane to MA is 21.7 $\mathrm{kcal} / \mathrm{mol}$, corresponding to $\mathrm{H}$ abstraction from adsorbed 2,5dihydrofuran. This result is not consistent with the current experimental interpretation, in which the rate-determining step is activation of the methylene $\mathrm{C}-\mathrm{H}$ bonds of $n$-butane with a barrier of $12.9-23.6 \mathrm{kcal} / \mathrm{mol} .{ }^{6,25}$ This suggests that there may be alternative pathways for the subsequent steps of the $n$ butane to MA conversion that have barriers even lower than the $21.7 \mathrm{kcal} / \mathrm{mol}$ barrier we calculated. It is also possible that entropic effects on the surface at operating temperatures might provide lower effective reaction barriers than found in DFTcomputed pathways along minimum energy surfaces. However, the main goal of this preliminary mechanistic study is to demonstrate that the conversion of $n$-butane to MA at the $\mathrm{P}=$ $\mathrm{O}$ site on this surface is very facile, with a barrier of not more than $21.7 \mathrm{kcal} / \mathrm{mol}$.

In summary, we used DFT to determine the reaction mechanism for $n$-butane oxidation to MA on VPO surfaces. In contrast to previous suggestions, we found that surface $\mathrm{O}(1)=$ $\mathrm{P}$ (formed by oxidation of pyrophosphate to two orthophosphates) is the center that activates $n$-butane (barrier of 13.5 $\mathrm{kcal} / \mathrm{mol}$ ). This high reactivity of $\mathrm{O}(1)=\mathrm{P}$ is due to its strong basicity coupled with the large reduction potentials of nearby $\mathrm{V}^{\mathrm{V}}$ ions. We have also demonstrated a full reaction pathway on this surface for oxidation of $n$-butane all the way to maleic anhydride with an overall barrier not exceeding $21.7 \mathrm{kcal} / \mathrm{mol}$. This is consistent with the reaction proceeding down to 673$723 \mathrm{~K}$.

Our results provide novel concepts for both heterogeneous and homogeneous catalysis. They suggest that pyrophosphate or phosphate is catalytically important and that it is critical to the function of the current VPO system and likely to play a similar role in other heterogeneous systems. They also provide the new concept of designing catalysts that use nonmetal-oxo bonds instead of metal-oxo bonds or metals for homogeneous alkane $\mathrm{C}-\mathrm{H}$ activation.

\section{ASSOCIATED CONTENT}

\section{S Supporting Information}

Computational details and additional results. This material is available free of charge via the Internet at http://pubs.acs.org.

\section{AUTHOR INFORMATION}

\section{Corresponding Author}

wag@wag.caltech.edu

Notes

The authors declare no competing financial interest.

\section{ACKNOWLEDGMENTS}

This work was initiated with support from the Center for Catalytic Hydrocarbon Functionalization, an Energy Frontier
Research Center (DOE DE-SC0001298), and completed with support from Chevron USA Inc. and NSF (CHE-1214158).

\section{REFERENCES}

(1) (a) Hodnett, B. K. Heterogeneous Catalytic Oxidation; Wiley: New York, 2000. (b) Centi, G.; Trifiro, F.; Ebner, J. R.; Franchetti, V. M. Chem. Rev. 1988, 88, 55.

(2) (a) Cheng, M. J.; Nielsen, R. J.; Tahir-Kheli, J.; Goddard, W. A., III. Phys. Chem. Chem. Phys. 2011, 13, 9831. (b) Thompson, D. J.; Fanning, M. O.; Hodnett, B. J. Mol. Catal. A: Chem. 2003, 198, 125. (c) Schiøtt, B.; Jørgensen, K. A.; Hoffmann, R. J. Phys. Chem. 1991, 95, 2297.

(3) Gleaves, J. T.; Ebner, J. R.; Kuechler, T. C. Catal. Rev. Sci. Eng. 1988, 30, 49.

(4) Chen, B.; Munson, E. J. J. Am. Chem. Soc. 2002, 124, 1638.

(5) Agaskar, P. A.; Decaul, L.; Grasselli, R. K. Catal. Lett. 1994, 23, 339.

(6) Schuurman, Y.; Gleaves, J. T. Ind. Eng. Chem. Res. 1994, 33, 2935.

(7) Busca, G.; Centi, G.; Trifiro, F.; Lorenzelli, V. J. Phys. Chem. 1986, 90, 1337.

(8) Yin, X.; Han, H.; Endou, A.; Kubo, M.; Teraishi, K.; Chatterjee, A.; Miyamoto, A. J. Phys. Chem. B 1999, 103, 1263.

(9) CRC Handbook of Chemistry and Physics, 92nd ed.; Haynes, W. M., Ed.; CRC Press: Boca Raton, FL, 2011.

(10) (a) Kung, H. H. Ind. Eng. Chem. Prod. Res. Dev. 1986, 25, 171. (b) Joly, J. P.; Mehier, C.; Bere, K. E.; Abon, M. Appl. Catal., A 1998, $169,55$.

(11) Ballhausen, C. J.; Gray, H. B. Inorg. Chem. 1962, 1, 111.

(12) Jin, N.; Ibrahim, M.; Spiro, T. G.; Groves, J. T. J. Am. Chem. Soc. 2007, 129, 12416.

(13) (a) Wachs, I. E.; Jehng, J.-M.; Deo, G.; Weckhuysen, B. M.; Guliants, V. V.; Benziger, J. B. Catal. Today 1996, 32, 47. (b) Wachs, I. E.; Jehng, J.-M.; Deo, G.; Weckhuysen, B. M.; Guliants, V. V.; Benziger, J. B.; Sundaresan, S. J. Catal. 1997, 170, 75.

(14) (a) Volta, J. C. Catal. Today 1996, 32, 29. (b) Hutchings, G. J.; Desmartinchomel, A.; Olier, R.; Volta, J. C. Nature 1994, 368, 41.

(15) Coulston, G. W.; Bare, S. R.; Kung, H.; Birkeland, K.; Bethke, G. K.; Harlow, R; Herron, N.; Lee, P. L. Science 1997, 275, 191.

(16) (a) Shimoda, T.; Okuhara, T.; Misono, M. Bull. Chem. Soc. Jpn. 1985, 58, 2163. (b) Koyano, G.; Okuhara, T.; Misono, M. J. Am. Chem. Soc. 1998, 120, 767.

(17) Guliants, V. V.; Benziger, J. B.; Sundaresan, S.; Yao, N.; Wachs, I. E. Catal. Lett. 1995, 32, 379.

(18) Ganduglia-Pirovano, M. V.; Popa, C.; Sauer, J.; Abbott, H.; Uhl, A.; Baron, M.; Stacchiola, D.; Bondarchuk, O.; Shaikhutdinov, S.; Freund, H. J. J. Am. Chem. Soc. 2010, 132, 2345.

(19) (a) Alptekin, G. O.; Herring, A. M.; Williamson, D. L.; Ohno, T. R.; McCormick, R. L. J. Catal. 1999, 181, 104. (b) Marcu, I. C.; Sandulescu, I.; Millet, J. M. M. J. Mol. Catal. A: Chem. 2003, 203, 241.

(20) Arnold, E. W.; Sundaresan, S. Appl. Catal. 1988, 41, 225.

(21) Hutchings, G. J. Catal. Lett. 2001, 75, 1.

(22) Shilov, A. E.; Shul'pin, G. B. Chem. Rev. 1997, 97, 2879.

(23) (a) Dietl, N.; Engeser, M.; Schwarz, H. Angew. Chem., Int. Ed. 2009, 48, 4861. (b) de Petris, G.; Troiani, A.; Rosi, M.; Angelini, G.; Ursini, O. Chem.-Eur. J. 2009, 15, 4248.

(24) Kubias, B.; Rodemerck, U.; Zanthoff, H. W.; Meisel, M. Catal. Today 1996, 32, 243.

(25) Pepera, M. A.; Callahan, J. L.; Desmond, M. J.; Milberger, E. C.; Blum, P. R.; Bremer, N. J. J. Am. Chem. Soc. 1985, 107, 4883. 